\title{
Impact of silver nanoparticles on wastewater treatment in the SBR
}

\author{
Magdalena Madeła ${ }^{1, *}$ \\ ${ }^{1}$ Institute of Environmental Engineering, Czestochowa University of Technology, Brzeznicka 60a, 42-200 Czestochowa, Poland
}

\begin{abstract}
The commonly application of nanoparticles (NPs) in commercial and industrial products inevitably increases their release into the natural environment which poses a threat to human health and ecosystems. A recent study of nanoparticles in wastewater treatment showed that most NPs are retained in the equipment used for biological wastewater treatment. The aim of the study was to determine the effects of silver nanoparticles (Ag NPs) on wastewater treatment in the SBR bioreactor. The effluent from the SBRs was analyzed for total organic carbon (TOC), suspended solids (SS), $\mathrm{pH}$ and total silver. Microbial observations of activated sludge were made and, on this basis, the Madonia biotic index was specified. After nanoparticles were added, the composition of microorganism communities of the activated sludge changed, and the largest community was the one of creeping ciliates. The efficiency of the effluent treatment measured by the concentration of TOC removal showed that Ag NPs were found to have remarkable effects on TOC removal in the SBR. The obtained results showed that purified wastewater included a low concentration of Ag nanoparticles. The main removal pathway of Ag NPs was via sorption as well as possible aggregation and sedimentation onto the sludge.
\end{abstract}

\section{Introduction}

Nowadays, due to various physical and chemical properties of AgNPs silver nanoparticles, there is growing interest in utilizing them in commercial products; they have become the most widely used nanomaterial (435 products) [1]. The world production of AgNPs oscillated between 300 and 1000 tons in 2015 [2]. Such a ubiquitous use of AgNPs is a serious hazard to the natural environment. Silver nanoparticles may be released into sewage through: antimicrobial agents and coatings, personal care products, soft goods, paints, varnishes as well as domestic appliances [2, 3, 4].

Obviously, all the processes which enable NPs removal from sewage, such as aggregation, sedimentation and biosorption through biomass lead to their agglomeration in activated sludge during the treatment process $[5,6]$. Silver nanoparticles seriously affect microorganisms living in activated sludge and play an essential role in the proper wastewater treatment since they restrain their activity and significantly reduce their number. Metal nanoparticles in aquatic environments may generate reactive oxygen species such as $\mathrm{OH}^{-}, \mathrm{O}_{2}$ and $\mathrm{H}^{+}$. As a result of electrostatic forces, positively charged nanoparticles may engage in interaction with negatively charged bacterial cell walls. Antimicrobial metal ions may be formed due to the presence of radicals [7, 8]. The research by Zapór [9] proved that the most toxic silver nanoparticles are the ones with the size of less than $10 \mathrm{~nm}$. Nanoparticles AgNPs can stunt the production of bacterial enzymes which are responsible for metabolism and the cell cycle and cause change the structure of the activated sludge flocs [10]. The nanoparticals bactericidal activity is the more efficient the smaller the size of the nanoparticles [11]. As a result, nanoparticles may negatively affect the sewage treatment process [12]. Zhang and others concluded that the concentration of up to $0.10 \mathrm{mg} / \mathrm{L}$ did not have any impact on the efficiency of sewage treatment because of the fact that activated sludge was capable of reducing toxicity of nanosilver through adsorption or precipitation of AgNPs and $\left(\mathrm{Ag}^{+}\right)$silver ions. However, they observed that at the exposure of $10 \mathrm{mg} / \mathrm{L}$ of AgNPs the biomass significantly decreased and the cell membrane was damaged. A big number of AgNPs agglomerated on the surface of cells and even inside of them [13].

In his studies, Kaegi obtained $95 \%$ removal of silver nanoparticles, which penetrated into sewage sludge, were removed during the sewage treatment process. It was assessed that the remaining $5 \%$ was retained in the purified sewage [14]. The research proved that the majority of silver nanoparticles migrated to the sludge during sewage treatment in the form of $\mathrm{Ag}_{2} \mathrm{~S}[15,16]$, which may remain in the sludge for a long time and be a source of toxic silver ions $[14,15,16]$. Ag nanoparticles

\footnotetext{
* Corresponding author: madelam@is.pcz.czest.pl
} 
present in soft goods can be transformed into $\mathrm{AgCl}$ and in this form reach the sewage works. They are likely to remain in this form in the sludge, which is quite important as $\mathrm{AgCl}$ is only slightly soluble and much less reactive than $\mathrm{Ag}$ [17].

Sewage sludge can be burnt or used as fertiliser in agriculture, and it is therefore a major source of exposure of ecosystem to silver nanoparticles [18, 19]. Thus, further managing sewage sludge may bring about serious risk to the natural environment by both the soil and water contamination and their negative effect on plants and bacteria in the rhizosphere [20].

The aim of the study was to determine what effect AgNPs silver nanoparticles had on the efficiency of treatment of sewage in the SRB bioreactor.

\section{Materials and methods}

\subsection{Waste water}

Synthetic sewage was used, prepared in accordance with slightly modified $\mathrm{Gu}$ procedure [21]. The sewage was prepared as glucose-based solution supplied with the following trace elements: $\mathrm{NH}_{4} \mathrm{Cl}-4.5 \mathrm{~g} / \mathrm{L}, \mathrm{K}_{2} \mathrm{HPO}_{4}$ $4.5 \mathrm{~g} / \mathrm{L}, \mathrm{MgSO}_{4}-1.95 \mathrm{~g} / \mathrm{L}, \mathrm{NaCl}-9 \mathrm{~g} / \mathrm{L}, \mathrm{CaCl}_{2}-0.45$ $\mathrm{g} / \mathrm{L}$ and $\mathrm{K}_{2} \mathrm{HPO}_{3}-4.5 \mathrm{~g} / \mathrm{L}$.

\subsection{Silver nanoparticles}

In the research, two types of silver nanoparticles were used. The first type was in the form of nanopowder, where the nanoparticle size was $<100 \mathrm{~nm} ;$ PVP (Polyvinylpyrrolidone) was applied as a dispergator. The second type of silver nanoparticles was in the colloidal nanocrystal form with the nominal silver content of $10 \%$ $\mathrm{v} / \mathrm{v}$ and the nanoparticle size $<20 \mathrm{~nm}$. They are in the form of aqueous dispersion of nano-Silver with stabilizing agents, consisting of $4 \% \mathrm{w} / \mathrm{w} \%$ each of Polyoxyethylene Glycerol Trioleate and Polyoxyethylene (20) Sorbitan mono-Laurat (Tween 20). The nanoparticle suspension was under ultrasound treatment for 1 hour, the ultrasound machine was Sonics Vibra-Cell VCX 134 (power $134 \mathrm{~W}$, frequency $40 \mathrm{kHz}$ ). The silver nanoparticles with the concentration of $2 \mathrm{mg} / \mathrm{L}$ were added to the sewage starting from the $30^{\text {th }}$ day of the research.

\subsection{Sequencing batch reactor}

The experiment was conducted in three parallel SBR bioreactors, each with the working volume of $3.5 \mathrm{~L}$ (SBR1- testing bioreactor, SBR2- bioreactor with AgNPs $<100 \mathrm{~nm}$, SBR3- bioreactor with AgNPs $<$ $20 \mathrm{~nm})$. The reactors were equipped with paddles having rotational speed regulation $(50 \mathrm{rpm})$ and aeration control. The air was provided by diffusers at the bottom of the tank. During aeration, the dissolved oxygen was maintained at the level of $5 \mathrm{mg} / \mathrm{L}$. One of the bioreactors served as a testing one, and no nanoparticles were supplemented into it. The sludge used in the study was taken from the municipal sewage works in Czestochowa. It was acclimated to synthetic sewage. The study was carried out at room temperature.

The SBRs were operated in a $12 \mathrm{~h}$ cycle mode. Each cycle consisted of the five following phases: I - filling and mixing, II - mixing and aeration, III - mixing, IV settling and decanting, $\mathrm{V}$ - stopping zone. The duration of each phase is listed in Table 1 .

Table. 1 The duration of each phase of the reactor formation

\begin{tabular}{|c|c|}
\hline Phase & Time, $\mathbf{h}$ \\
\hline filling and mixing & 1.0 \\
mixing and aeration & 8.5 \\
mixing & 1.0 \\
settling and decanting & 1.0 \\
stopping zone & 0.5 \\
\hline
\end{tabular}

The bioreactors worked with a sludge retention time (SRT) equalling $12 \mathrm{~h}$ and HRT (hydraulic retention time) equalling $4 \mathrm{~h}$ respectively. The experiment lasted 40 days.

\subsection{Analitytical method}

The measurement of contaminants in the sewage covered: organic carbon (TOC), suspended solids (SS), volatile suspended solids (VSS), $\mathrm{pH}$ and total silver. TOC was analysed with the use of the multi N/C 3100 as the organic carbon remaining in an acidified sample after purging the sample with gas. SS, VSS and $\mathrm{pH}$ were measured in compliance with APHA [22].

Silver concentration was evaluated by means of the atomic absorption spectrometry method using SpectroAcros ICP-OES.

In the experiment the researchers observed sludge which was microbiologically activated and, on this basis, they calculated the Sludge Biotic Index (SBI) proposed by Madoni [23]. Microscopic pbservations were carried out using an Olympus BX 41 microscope at 100x magnification. The index showed varying protozoa sensitivities to the environmental conditions of the activated sludge. The Sludge Biotic Index ranges from 0 to 10 . The SBI values are grouped into four quality classes: Class I including SBI values: 10, 9 and 8; Class II including 7 and 6; Class III including 5 and 4; Class IV including the remaining values. The observations were made with the use of the appropriate diagnostic values [23].

\section{Results and discussion}

The study was carried out in three bioreactors SBR1, SBR2, and SBR3, which were formed for 30 days. The initial value of TOC concentration was $150 \mathrm{mg} / \mathrm{L}$. The obtained efficiency of removing TOC was more than 90 $\%$. Next, the bioreactors were supplemented with proper silver nanoparticles with the concentration of $2 \mathrm{mg} / \mathrm{L}$ for the period of 10 days. Figures 1-3 show the results of removing TOC in the analysed bioreactors. 


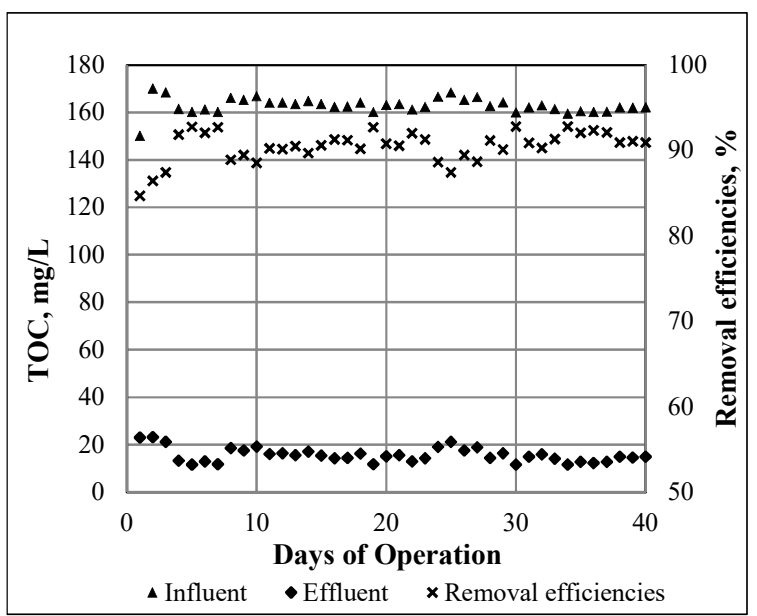

Fig. 1. The changes in TOC removal in the testing sequencing batch reactor (SBR1)

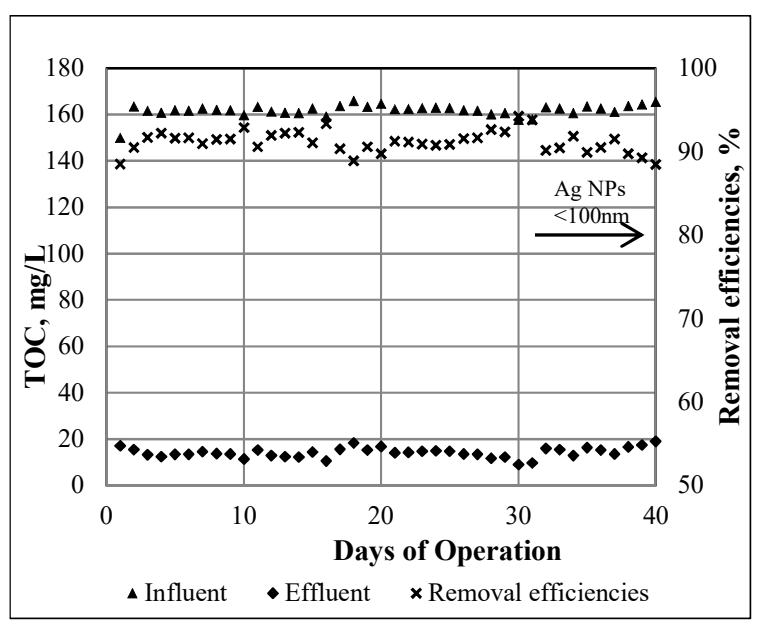

$* \longrightarrow$ The time of AgNPs dosing

Fig. 2. The effect of AgNPs 100 on TOC removal in the sequencing batch reactor (SBR2)

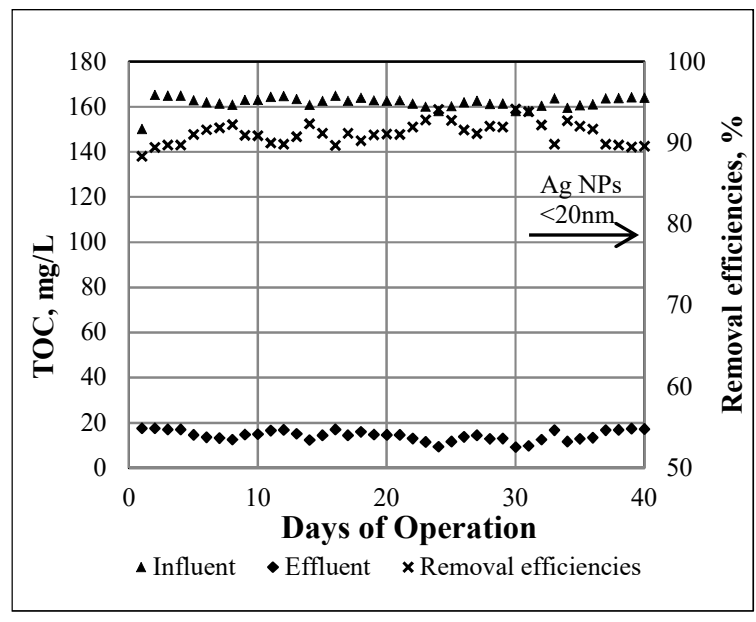

$* \longrightarrow$ The time of AgNPs dosing

Fig. 3. The effect of AgNPs 20 on TOC removal in the sequencing batch reactor (SBR3)
Figure 2 presents the results of removing TOC in bioreactor SBR2 which was supplied with silver nanoparticles in the form of nanopowder with the size of less than $100 \mathrm{~nm}$. The study showed the decrease of efficiency in the removal of TOC to $88.48 \%$. Slightly better results were observed in the case of smaller nanoparticles - the efficiency of removing TOC dropped to $89.56 \%$ (Figure 3 ). In the case of the testing bioreactor (SBR1), the removal of TOC in the compared period oscillated between 90.27 to $92.80 \%$ (Figure 1). Thus, AgNPs seems to have no special effect on the removal of TOC from sewage. Qiu [24] also proved that using concentration of nanoparticles of $1.0 \mathrm{mg} / \mathrm{L}$ had a very slight impact on the decrease of COD (decrease of a few percent). The research undertaken by $\mathrm{Xu}$ and others [25] showed that concentrations of nanoparticles ranging from 2 to $30 \mathrm{mg} / \mathrm{L}$ only slightly diminished the efficiency of removing pollutants.

Figure 4 presents changes in the suspended solids (SS) and volatile suspended solids (VSS) in the analysed bioreactors during sewage treatment. There was observed a distinct growth of SS and VSS till the $10^{\text {th }}$ day, then, while the bioreactor was being formed, the values started to fluctuate. After nanoparticles were added to bioreactors SBR2 and SBR3, there were no significant changes in the values, however in bioreactor SBR3 a slight decrease of SS and VSS values was observed. In bioreactor SBR1, the concentrations of SS and VSS remained similar till the end of the experiment. It seems that the presence of nanoparticles in sewage reduces the speed of removing pollutants during the process - the lower SS value becomes, the bigger organic load on sludge flocs is, which translates to a less effective reduction of pollutants from sewage.

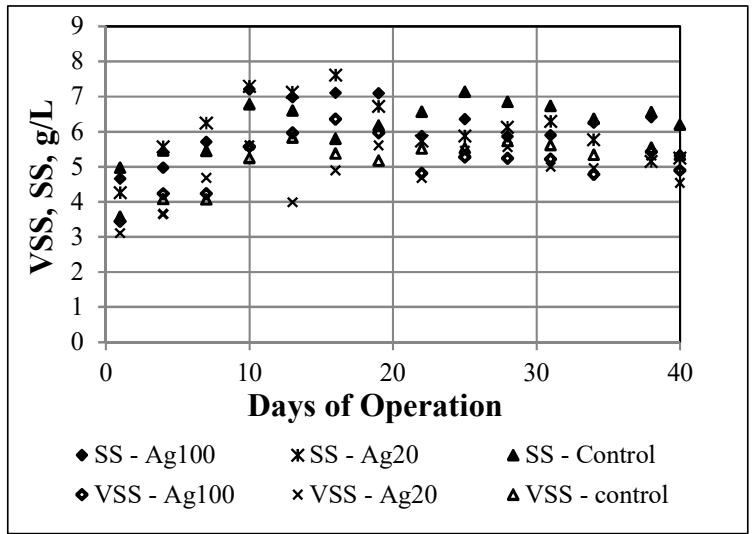

Fig. 4. The effect of different AgNPs on suspended solids and volatile suspended solids in the SBR effluents

During the experiment, $\mathrm{pH}$ values of sewage in reactors SBR1, SBR2 and SBR3 (Figure 5) changed. The initial $\mathrm{pH}$ values ranged between $6.45-6.82$, in the course of 30 days of the activated sludge acclimating to become synthetic sewage. $\mathrm{pH}$ values fluctuated and a slight drop was observed in them. On the $30^{\text {th }}$ day, before AgNPs were added, $\mathrm{pH}$ values in the bioreactors were similar and amounted to about 6.37. After silver 
nanoparticles were supplied, there was a drop in the $\mathrm{pH}$ and then an increase up to the initial value on the $38^{\text {th }}$ day of the experiment. However, similar dependence occurred in the testing bioreactor SBR1, therefore it would be unjustifiable to claim that the change in $\mathrm{pH}$ values was caused by the exposure to nanoparticles.

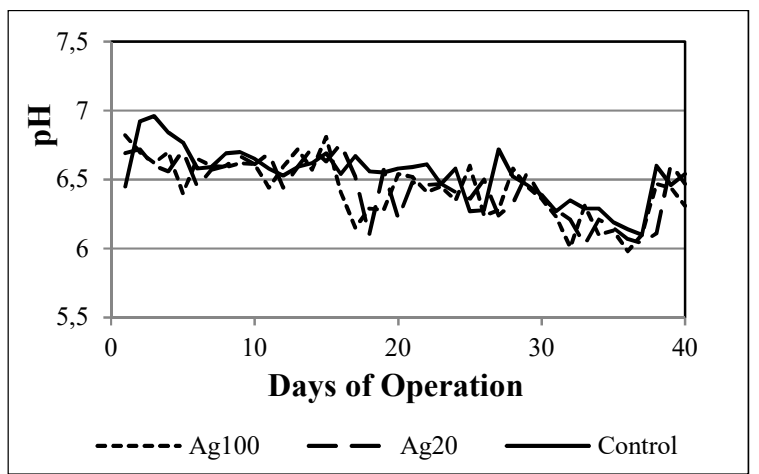

Fig. 5. The changes in $\mathrm{pH}$ value during the experiment in the bioreactors

Based on the microscopic observation of the activated sludge after AgNPs nanoparticles were supplied, one may conclude that the number of microbes underwent a change. The calculated SBI values as well as the activated sludge class are listed in Table 2. The changes in the dominant microorganism communities which are responsible for the proper functioning of the activated sludge caused a decrease in the SBI value [26, 27]. The obtained SBI values enabled classification of the activated sludge.

Table 2. Sludge Biotic Index and class for the activated sludge in individual SBRs depending on the added nanoparticles to wastewater

\begin{tabular}{|c|c|c|c|c|c|c|}
\hline \multicolumn{2}{|c|}{} & \multicolumn{5}{|c|}{ Operations time } \\
\cline { 3 - 7 } \multicolumn{2}{|c|}{ Marking } & 30 & 31 & 34 & 38 & 40 \\
\hline the Sludge & SBR1 & 9 & 9 & 9 & 9 & 8 \\
Biotic Index & SBR2 & 8 & 8 & 8 & 9 & 8 \\
(SBI) & SBR3 & 8 & 9 & 8 & 8 & 8 \\
The class of & SBR1 & I & I & I & I & I \\
the activated & SBR2 & I & I & I & I & I \\
sludge & SBR3 & I & I & I & I & I \\
\hline
\end{tabular}

Microscopic analysis of the sludge showed (Figure 6) that testate amoebae constituted $40.57 \%$, attache ciliates $-23.53 \%$ and free swimming ciliates $-23.73 \%$ of the dominant communities of protozoa in the testing bioreactor SBR1. The dominant communities in SBR2 and SBR3 were creeping ciliates amounting to $56.68 \%$ and $57.36 \%$ respectively. In both reactors, the number of attache ciliates and testate amoebae decreased. Protozoa are necessary to reduce pollutants in sewage. As long as the sludge load is not very big, protozoa are present in the activated sludge and constitute a few percent of the total biomass [28]. The largest community of amoebae in the experiment was testate amoebae. The presence of ciliates and testate amoebae testifies that the sludge was old enough and well aerated. The characteristic feature of the sludge containing those microorganisms is that it has little loading [28].

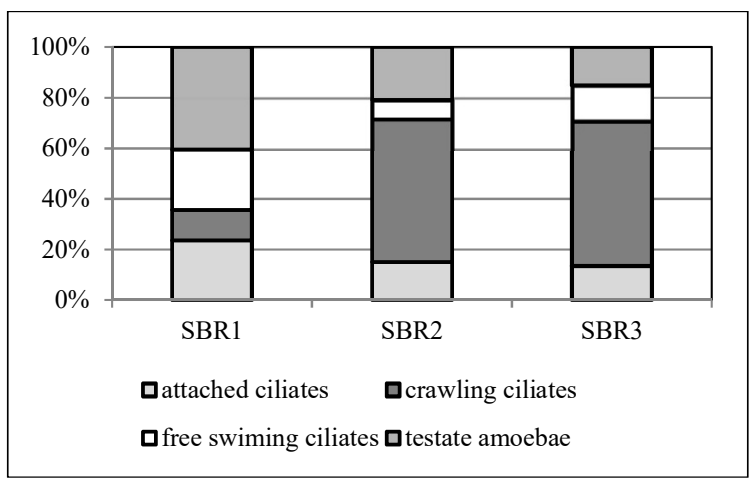

Fig. 6 The dominant structure of ciliate communities in the activated sludge in the bioreactors

During the experiment, the SBI value in all the three bioreactors equalled $8-9$, reaching Class I according to Madoni (Table 2); the activated sludge was stable and properly colonised.

The results of removing the above-mentioned two types of nanoparticles from sewage in bioreactors SBR2 and SBR3 are presented in Figure 7. After silver nanoparticles with the concentration of $2 \mathrm{mg} / \mathrm{L}$ of AgNPs were added to the bioreactors, they were found in case of SRB2 in the amount of $0.0076 \mathrm{mg} / \mathrm{L}$ in the purified sewage only on the $5^{\text {th }}$ day of the experiment, while in case of SRB3 the total silver concentration equalled $0.00347 \mathrm{mg} / \mathrm{L}$ on the $4^{\text {th }}$ day. In studies obtained 99\% removal of AgNPs through the activated sludge within 24 hours using the concentration of 1 $\mathrm{mg} / \mathrm{L}$ of AgNPs [29]. As it may easily be seen in the graph, silver nanoparticles of the bigger size $($ AgNPs $<100 \mathrm{~nm})$ were more effectively removed from sewage than smaller nanoparticles (AgNPs $<20 \mathrm{~nm})$. This may result from the better antimicrobial properties of silver nanoparticles of smaller sizes [30].

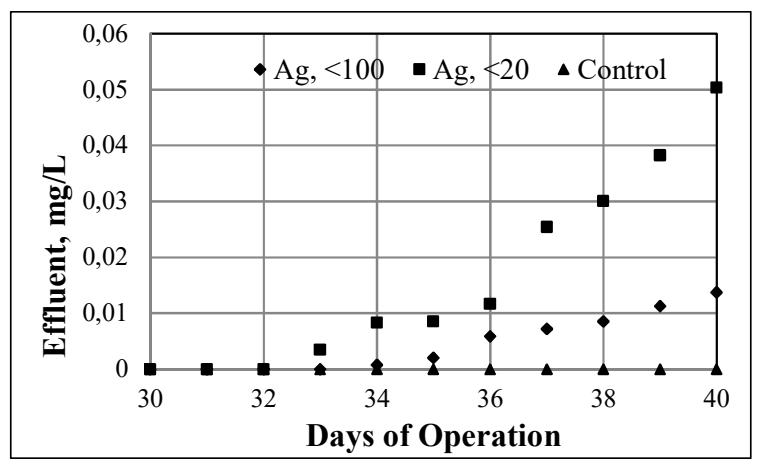

Fig. 7. The changes in the total silver concentration in the purified sewage from the bioreactors

During the study, the concentrations of silver nanoparticles were calculated (in the form of total silver) 
in sewage, whose acceptable value for silver is $0.1 \mathrm{mg}$ of $\mathrm{Ag} / \mathrm{L}$ (under the Regulation of the Minister of the Environment of 18 November 2014 on the conditions to be met as regards the release of sewage into water or onto land and on the substances that are particularly harmful to the aquatic environment). The silver concentration was exceeded in the case of reactor SBR3 on the $36^{\text {th }}$ day, and in the case of SBR2 on the $39^{\text {th }}$ day of the experiment (Figure 7). That is why, one cannot assume that silver nanoparticles, which may pose a real threat to the aquatic environment, are definitely not present in the purified sewage.

\section{Conclusions}

In this study, the researchers examined what influence various AgNPs silver nanoparticles with the concentration of $2 \mathrm{mg} / \mathrm{L}$ had on the biological process of sewage treatment in the SBR reactor. This concentration of nanoparticles in sewage did not influence the removal of TOC during sewage treatment in the SBR very much. The lowest degree of TOC removal in case of SRB2 and SRB3 amounted to $88.48 \%$ and $89.45 \%$ respectively. No significant changes were observed to the activated sludge formation during exposure to silver nanoparticles with the concentration of $2.0 \mathrm{mg} / \mathrm{L}$. However, after nanoparticles were added, the composition of microorganism communities of the activated sludge changed, and the largest community was the one of creeping ciliates. Thanks to the presence of attache, creeping, free swimming ciliates as well as testate amoebae the activated sludge was stable, properly aerated and with little loading.

Silver nanoparticles were effectively removed from sewage during the first days of the process. However, at the end of the study, a major part of AgNPs with the concentration of $0.0137 \mathrm{mg} / \mathrm{L}$ and $0.0504 \mathrm{mg} / \mathrm{L}$ remained in the purified sewage. Therefore, one cannot assume that silver nanoparticles, which may pose a real threat to the aquatic environment, are definitely not present in the purified sewage.

\section{Acknowledgements}

Publication supported by the Polish Ministry of Science and Higher Education as a part of the program of activities disseminating science from the project „Organization of the First International Science Conference - Ecological and Environmental Engineering”, 26-29 June 2018, Kraków.

The research was funded by the project No. BS-PB401/301/13.

\section{References}

1. M.E. Vance, T. Kuiken, E.P. Vejerano, S.P. McGinnis, M.F. Hochella Jr, D. Rejeski, M.S. Hull, Beilstein journal of nanotechnology, 6, pp.1769 (2015).
2. C.M. Whiteley, M. Dalla Valle, K.C. Jones, A.J. Sweetman, Environmental Science: Processes \& Impacts, 15, 11, pp. 2050-2058 (2013)

3. I. Krzyżewska, J. Kyzioł-Komosińska, C. RosikDulewska, J. Czupioł, P. Antoszczyszyn-Szpicka, Archives of Environmental Protection, 42, 1, pp. 87101 (2016)

4. M. Madeła, E. Neczaj, M. Worwąg, A. Grosser, Chemical Industry, 94 , pp. 2138-2141 (2015)

5. F. Gottschalk, T. Sonderer, R. W. Scholz, Nowack Environmental Sciences Technology, 43, pp. 92169222 (2009)

6. M.A. Kiser, H. Ryu, H. Jang, K. Hristovski, P. Westerhoff, Water Research , 44, 14, pp. 4105-4114 (2010)

7. J.J. Guerard, P.L. Miller, T.D. Trouts, Y.P. Chin, Aquatic Sciences, 71, pp. 160-169 (2009)

8. P.J.P. Espitia, N.F.F. Soares, J.S. dos Reis Coimbra, N.J. de Andrade, R.S. Cruz, E.A.A. Medeiros, Food and Bioprocess Technology, 5, pp. 1447-1464 (2012)

9. L. Zapór, Archives of environmental protection, 42, 4, pp.32-47 (2016)

10. Z. Sheng, Y. Liu, Water Research, 45, pp. 6039$6050(2011)$

11. G.A. Martinez-Castanon, N. Nino-Martinez, F. Martinez-Gutierrez, J.R. Martinez-Mendoza, F. Ruiz, Journal of Nanoparticle Research, 10, 8, pp.1343-1348 (2008)

12. K.L. Garner, A.A. Keller, Journal of Nanoparticles Research, 16, 8, pp. 1-28 (2014)

13. C. Zhang, Z. Liang, Z. Hu, Water Research, 50, pp.350-358 (2014)

14. R. Kaegi, A. Voegelin, B. Sinnet, S. Zuleeg, H. Hagendorfer, M. Burkhardt, H. Siegrist, Environmental science \& technology, 45, 9, pp.3902-3908 (2011)

15. B. Kim, C. S. Park, M. Murayama, M.F. Hochella Jr, Environmental science \& technology, 44, 19, pp.7509-7514 (2010)

16. R. Kaegi, A. Voegelin, C. Ort, B. Sinnet, B. Thalmann, J. Krismer, E. Mueller, Water Research, 47, 12, pp.3866-3877 (2013)

17. C. A. Impellitteri, T.M. Tolaymat, K.G. Scheckel, Journal of environmental quality, 38, 4, pp.15281530 (2009)

18. B. P. Colman, C.L. Arnaout, S. Anciaux, C.K. Gunsch, M.F. Hochella Jr, B. Kim, J.M. Unrine, PLoS One, 8, 2, e57189 (2013)

19. K. Schlich, T. Klawonn, K. Terytze, K. HundRinke, Environmental Sciences Europe, 25, 1, pp.17 (2013)

20. M. Madeła, E. Neczaj, A. Grosser, Engineering and Environmental Protection, 19, 4, pp.577-587 (2016)

21. L. Gu, Q. Li, X. Quan, Y. Cen, X. Jiang, Water Research, 58, pp.62-70 (2014)

22. APHA-AWWA-WEF, Standard methods for the examination of water and wastewater. 18th Edition (1992)

23. P. Madoni, Water Research, 28, 1, pp. 67-75 (1994)

24. G. Qiu, K. Wirianto, Y. Sun, Y.P. Ting, Journal of Cleaner Production, 130, pp. 137-142 (2016) 
25. Q. Xu, S. Li, Y. Wan, S. Wang, B. Ma, Z. She, J. Dong, Journal of environmental management, 204, pp.667-673 (2017)

26. A.L. Amaral, M. Motta, M.N. Pons, H. Vivier, E.C. Ferreira, International Chemical Engineering, 8, pp.1137-1144 (2001)

27. P. Madoni, D. Davoli, G. Gorbi, Water Research, 30, 1, pp.135-141 (1996)
28. D.H. Eikelboom, Latimer Trend\&Co Ltd, Plymounth, UK 2000 (2000)

29. H.J. Park, H.Y. Kim, S. Cha, C.H. Ahn, J. Roh, S. Park, J. Yoon, Chemosphere, 92, pp.524-528 (2013)

30. J.R. Morones, J.L. Elechiguerra, A. Camacho, Nanotechnology, 16, 10, pp. 2346-2353 (2005) 